\title{
Hubungan Lama Penggunaan Obat Anti Nyamuk Bakar dengan Kadar Kolinesterase Darah pada Masyarakat Kelurahan Jati Rumah Gadang Padang
}

\author{
Amelia $^{1}$,Yustini Alioes ${ }^{2}$, Sofina Rusdan ${ }^{3}$
}

\begin{abstract}
Abstrak
Pada saat ini, pestisida banyak digunakan dalam bidang pertanian, namun pestisida juga masuk ke dalam rumah tangga untuk membasmi hewan pengganggu dan penyebab penyakit, yaitu berupa insektisida yang terdapat dalam obat anti nyamuk bakar yang dapat menimbulkan pengaruh negatif terhadap kesehatan manusia. Tujuan penelitian ini adalah untuk mengetahui hubungan lama penggunaan obat anti nyamuk bakar dengan kadar kolinesterase darah pada masyarakat kelurahan Jati Rumah Gadang Padang. Desain penelitian ini adalah cross sectional study dengan populasi masyarakat di Kelurahan Jati Rumah Gadang Padang. Pemilihan subjek secara accidental sampling mendapatkan 23 responden. Pemeriksaan kadar kolinesterase menggunakan alat spektrofotometri. Data dianalisis dengan uji chi-square. Hasil uji statistik menunjukan tidak terdapat hubungan yang bermakna antara lama pemakaian obat anti nyamuk bakar dengan penurunan kadar kolinesterase $(p=0.395)$, namun berisiko untuk terjadi penurunan kadar kolinesterase dengan $\mathrm{OR}=4.250$ pada masyarakat Kelurahan Jati Rumah Gadang Padang. Kesimpulan penelitian ini adalah penggunaan obat anti nyamuk bakar berisiko untuk terjadi keracunan.
\end{abstract}

Kata kunci: obat anti nyamuk bakar, kolinesterase, insektisida

\section{Abstract}

In this time, pesticide is not only used by agriculture sector but also used by household sector to eradicate insects and disease agents, one of them is anti mosquito fuel which contain insecticide. Insecticide is kind of dangerous chemical substance which can give a negative effect to the human health. The objective of this study was to determine correlation between prolonged use of anti mosquito fuel and cholinesterase concentration to Kelurahan Jati Rumah Gadang Padang society. This was a cross sectional study which population are society in Kelurahan Jati Rumah Gadang Padang. The subjects were 23 persons which chosen by using accidental sampling methode. Cholinesterase examination used spectrophotometric. It was analyzed by chi-square correlation test by tofor Windows. The result showed, there was no significant correlation $(p=0,395)$ between prolonged use of anti mosquito fuel with decreasing of cholinesterase concentration but it risked to decrease the cholinesterase concentration (OR=4.250) of Kelurahan Jati Rumah Gadang Padang society. The conclusion of this research is the society whom used anti mosquito fuel it risked getting poisoned.

Keywords: anti mosquito fuel, cholinesterase, insecticide

Affiliasi penulis: 1. Pendidikan Dokter FK UNAND (Fakultas Kedokteran Universitas Andalas Padang), 2. Bagian Biokimia FK UNAND, 3. Bagian fisiologi FK UNAND

Korespondensi: Amelia, E-mail: ameliayusman@gmail.com, Telp: 085269990852

\section{PENDAHULUAN}

Acetylcholinesterase (AchE) yaitu enzim yang mengkatalisis pemecahan asetilkolin menjadi kolin dan asetat; ditemukan di susunan saraf pusat,sel darah merah dan otot rangka.Terganggunya aktifitas enzim 
ini dapat menyebabkan berbagai gejala klinis, seperti pusing, mual dan dapat menimbulkan gangguan pada sistem saraf. Salah satu penyebab terganggunya enzim ini adalah karena pemakaian pestisida. ${ }^{1,2}$ Penelitian yang diadakan di Kabupaten Magelang menunjukan $76,5 \%$ responden mengalami keracunan pestisida yang dilihat dari tingkat aktifitas kolinesterase darah responden. ${ }^{3}$

Pada saat ini, pestisida lebih didentikan dengan bidang pertanian namun tanpa disadari, pestisida juga berada di lingkungan dalam rumah tangga. Pestisida yang terdapat dalam lingkungan rumah tangga berguna untuk mengusir berbagai jenis serangga, misalnya nyamuk, kecoa, semut dan binatang kecil lainnya. Pestisida yang paling sering digunakan dalam rumah tangga adalah anti nyamuk. Terdapat jenis sediaan anti nyamuk, yaitu bakar, semprot, elektrik dan oles. ${ }^{4}$

Pusat Data dan Informasi Persatuan Rumah Sakit Indonesia (PERSI) di tahun 2006 menyatakan bahwa pemakaian obat anti nyamuk berbahaya bagi manusia karena mengandung bahan aktif yang termasuk golongan organophosfat dan karbamat. Bahan aktif dari organophosfat yaitu Dichorvos atau Dichlorovynil dimethyl phosfat (DDVP) dan bahan aktif dari karbamat yaitu propuxur yang merupakan jenis insektisida pembunuh serangga. Kandungan senyawa kimia yang terdapat pada obat anti nyamuk selain berupa propuxur dan diklorvos, senyawa lain yaitu pyrethroid, tranflutrin, dellatherine. ${ }^{4}$

WHO menetapkan diklorvos sebagai racun tingkat pertama yang mempunyai efek teratogenik yang membahayakan perkembangan janin dan mempunyai bahan aktif yang merusak sistem saraf, pernapasan dan ginjal. Obat anti nyamuk kandungannya juga ditambahkan S2 (octachloro dipropyl ether) yang mempunyai efek lebih ampuh untuk membunuh segala jenis serangga dan akan menjadi sangat berbahaya jika dibakar karena menghasilkan BMCE (bischloromethyl ether) yang mempunyai risiko kanker paru. ${ }^{5,6}$

WHO menetapkan bahwa yang dikatakan keracunan adalah bila terjadi penurunan kadar kolinesterase dalam darah $30 \%$ dari normal. Penggunaan obat anti nyamuk akan menyebabkan hambatan pada kolinesterase sehingga menyebabkan efek nikotinik dan muskarinik. Efek nikotinik yaitu efek pada reseptor nikotinik di gangglion dan dalam otot. Efek muskarinik yaitu efek pada otot jantung, otot polos dan kelenjar. Meningkatnya kadar pestisida dalam darah akan mengganggu metabolisme enzim asetilkolinesterase yang dapat menyebabkan iritabilitas, tremor, kejang-kejang. ${ }^{7,8}$

Obat anti nyamuk banyak beredar di pasaran dan harga anti nyamuk bakar relatif murah. Dari hasil penelitian pemilihan jenis pestisida dalam rumah tangga yang banyak digunakan berdasarkan kebiasaan (56\%) dan paling banyak kedua berdasarkan harga (53\%). Keampuhannya untuk membasmi nyamuk dengan cepat merupakan bahan pertimbangan bagi masyarakat untuk menggunakan obat anti nyamuk. Jenis anti nyamuk yang banyak digunakan dalam rumah tangga adalah jenis bakar (54\%) dan jenis semprot (19\%).,

Berdasarkan penjelasan diatas, perlu dilakukan penelitian untuk mengetahui hubungan lama penggunaan obat anti nyamuk bakar mengandung pestidida dengan penurunan kadar enzim kolinesterase dalam darah. Penelitian ini dilakukan di Kelurahan Jati Rumah Gadang Padang yang merupakan salah satu kelurahan binaan Fakultas Kedokteran Universitas Andalas.

\section{METODE}

Jenis penelitian yang digunakan adalah cross sectional study. Populasi penelitian ini adalah masyarakat di kelurahan Jati Rumah Gadang Padang yang berjumlah 473 orang. Subjek penelitian ini adalah masyarakat pengguna obat anti nyamuk bakar yang sudah diteliti kadar kolinesterase pada penelitian sebelumnya. Jumlah subjek yang diteliti adalah 30 orang. Subjek dipilih secara non random sampling, yaitu secara accidental sampling dimana masyarakat yang menjadi subjek didapatkan secara kebetulan bertemu dengan peneliti dengan ketentuan sesuai dengan kriteria inklusi. Kriteria inklusi dan ekslusi yang dipenuhi untuk pemilihan sampel adalah: Kriteria inklusi: (1) Masyarakat yang menggunakan obat anti nyamuk bakar di kelurahan Jati Padang. (2) Bersedia ikut dalam penelitian dengan penandatanganan 
informed consent. Kriteria eksklusi: (1) Tidak berada ditempat ketika penelitian dilakukan. (2) Menggunakan obat lain yang mempunyai efek sama dengan obat anti nyamuk bakar.

\section{HASIL}

Subjek yang memenuhi kriteria inklusi sebanyak 23 orang dan tujuh orang dieksklusikan karena tidak berada ditempat ketika penelitian dilaksanakan.

Tabel 1. Distribusi responden menurut jenis kelamin di Kelurahan Jati Rumah Gadang Padang

\begin{tabular}{ccc}
\hline $\begin{array}{c}\text { Jenis } \\
\text { Kelamin }\end{array}$ & $\mathbf{n}$ & $\%$ \\
\hline Laki-laki & 8 & 34,8 \\
Perempuan & 15 & 65,2 \\
\hline Total & 23 & 100,0 \\
\hline
\end{tabular}

Tabel 1 memperlihatkan jumlah responden perempuan lebih banyak dari pada jumlah responden laki-laki yaitu sebanyak 65,2\%.

Tabel 2. Distribusi responden berdasarkan umur di Kelurahan Jati Rumah Gadang Padang

\begin{tabular}{ccc}
\hline Umur & $\mathbf{n}$ & $\%$ \\
\hline $10-20$ tahun & 4 & 17,4 \\
20-30 tahun & 5 & 21,7 \\
$30-50$ ahun & 6 & 26,7 \\
$>50$ tahun & 8 & 35,8 \\
\hline Total & 23 & 100,0 \\
\hline
\end{tabular}

Berdasarkan Tabel 2 terlihat bahwa penggunaan obat anti nyamuk bakar terbanyak pada usia $>50$ tahun.

Tabel 3. Distribusi responden berdasarkan pendidikan terakhir di Kelurahan Jati Rumah Gadang Padang

\begin{tabular}{ccc}
\hline Pekerjaan & $\mathbf{n}$ & $\%$ \\
\hline SD & 3 & 13,0 \\
SMP & 10 & 43,5 \\
SMA & 9 & 39,1 \\
S1 & 1 & 4,3 \\
\hline Total & 23 & 100,0 \\
\hline
\end{tabular}

Berdasarkan Tabel 3 terlihat bahwa sebagian besar responden mempunyai pendidikan terakhir SMP/Sederajat, yaitu sebanyak $43,5 \%$.
Tabel 4. Distribusi responden berdasarkan pekerjaan di Kelurahan Jati Rumah Gadang Padang

\begin{tabular}{ccc}
\hline Pekerjaan & $\mathbf{n}$ & $\%$ \\
\hline PNS & - & - \\
Pedagang & - & - \\
Petani & - & - \\
Ibu RT & 11 & 47,8 \\
Dan lain-lain & 12 & 52,2 \\
\hline Total & 23 & 100,0 \\
\hline
\end{tabular}

Tabel 4 memperlihatkan sebagian responden memiliki pekerjaan sebagai lbu RT sebanyak 47,8\% dan yang memiliki pekerjaan Dan lain-lain (siswa, buruh bangunan dan tukang ojek) sebanyak $52,2 \%$.

Hasil penelitian yang telah dilakukan pada 23 responden didapatkan gangguan kesehatan yang banyak dikeluhkan adalah kejang otot lengan, sakit kepala, peningkatan sekresi air mata, batuk berdahak dan otot wajah kaku. Kadar kolinesterase masyarakat Kelurahan Jati Rumah Gadang Padang yang melakukan pemeriksaan dapat dilihat pada tabel berikut:

Tabel 5. Distribusi kadar kolinesterase masyarakat Kelurahan Jati Rumah Gadang Padang

\begin{tabular}{ccc}
\hline $\begin{array}{c}\text { Kadar } \\
\text { Kolinesterase }\end{array}$ & $\mathbf{n}$ & $\%$ \\
\hline Normal & 2 & 8,7 \\
Tidak Normal & 21 & 91,3 \\
\hline Total & 23 & 100,0 \\
\hline
\end{tabular}

Dari Tabel 5 dapat dilihat bahwa prevalensi rate kadar kolinesterase normal pada masyarakat Kelurahan Jati Rumah Gadang adalah 8,7\%, sedangkan prevalensi rate kadar kolinesterase tidak normal $91,3 \%$.

Tabel 6. Distribusi frekuensi lama penggunaan obat anti nyamuk bakar pada masyarakat Kelurahan Jati Rumah Gadang Padang

\begin{tabular}{ccc}
\hline $\begin{array}{c}\text { Lama } \\
\text { penggunaan }\end{array}$ & $\mathbf{n}$ & $\%$ \\
\hline$<5$ tahun & 5 & 21,7 \\
$\geq 5$ tahun & 18 & 78,3 \\
\hline Total & 23 & 100,0 \\
\hline
\end{tabular}

Tabel 6 menggambarkan sebanyak 78,3\% masyarakat Kelurahan Jati Rumah Gadang 
menggunakan obat anti nyamuk bakar dalam waktu

lebih dan sama dari lima tahun.

Tabel 7. Hubungan lama penggunaan obat nyamuk bakar dengan kadar kolinesterase darah masyarakat Kelurahan Jati Rumah Gadang Padang

\begin{tabular}{llccccc}
\hline $\begin{array}{c}\text { Kadar } \\
\text { kolinesterase }\end{array}$ & \multicolumn{1}{c}{ Lama penggunaan } & Total & $\%$ & p & OR \\
\hline & $<5$ & $\geq 5$ & & & & \\
Normal & $\mathrm{n}$ & $\mathrm{n}$ & 2 & 100,0 & 0,395 & $4,250(0,216-83,517)$ \\
\hline Tidak normal & 1 & 1 & 21 & 100,0 & & \\
\hline Total & 4 & 17 & 23 & & \\
\hline
\end{tabular}

Dari Tabel 7 dapat dilihat bahwa nilai $p=0,395$ (dimana nilai $\mathrm{p}$ yang dianggap bermakna adalah $<0,05)$, yang artinya tidak terdapat hubungan yang bermakna antara lama penggunaan obat anti nyamuk bakar dengan penurunan kadar kolinesterase darah dengan OR 4,250 dengan interval kepercayaan 0,216 sampai 83,517. Maknanya, responden yang menggunakan obat anti nyamuk bakar lebih atau sama dari 5 tahun berisiko 4,250 kali untuk terjadi penurunan kadar kolinesterase dibandingkan dengan responden yang menggunakan obat anti nyamuk bakar kurang dari 5 tahun.

\section{PEMBAHASAN}

Hasil pengukuran kadar kolinesterase yang telah dilakukan di Kelurahan Jati Rumah Gadang Padang menunjukan bahwa terdapat 21 responden mengalami penurunan kadar kolinesterase. Sebanyak sembilan responden yang mengalami penurunan kolinesterase tidak mengalami keracunan pestisida, kemungkinan disebabkan karena paparan kandungan yang terdapat obat anti nyamuk bakar masih rendah dan belum memenuhi kriteria yang ditetapkan WHO, hal ini sesuai dengan penelitian sebelumnya yang menyatakan bahwa terdapat hubungan antara penggunaan obat anti nyamuk bakar terhadap penurunan kadar kolinesterase darah.,3 Terdapat 12 responden yang mengalami penurunan kadar kolinesterase dikategorikan mengalami keracunan karena memiliki kadar kolinesterase kurang dai 30\% nilai normal, yaitu di bawah $2751 \mathrm{U} / \mathrm{L}$. Dua responden memiliki kadar kolinesterase masih dalam batas normal.
Berdasarkan penelitian yang telah dilakukan di Kelurahan Jati Rumah Gadang Padang, penurunan kadar kolinesterase terjadi pada 18 responden yang telah menggunakan obat anti nyamuk bakar $\geq 5$ tahun, 17 responden diantaranya mengalami penurunan kadar kolinesterase dan 1 responden memiliki kadar kolinesterase masih dalam batas normal. Responden yang menggunakan obat anti nyamuk bakar $<5$ tahun, 4 responden diantaranya mengalami penurunan dan 1 responden masih dalam batas normal.

Penelitian sebelumnya juga menyatakan bahwa lama paparan organofosfat dan karbamat tidak mempengaruhi karacunan, namun yang mempengaruhi adalah intensitas paparan. Hal ini terjadi karena sifat dari organofosfat yang irrevesibel, jika terjadi paparan dalam jumlah banyak maka akan terjadi keracunan dan apabila dihentikan paparannya, maka organofosfat akan menetap 2-6 minggu. Penggunaan kembali organofosfat dalam jumlah yang sedikit saja akan menyebabkan gejala bertambah berat, berbeda dengan golongan karbamat yang bersifat reversibel, apabila paparan dihentikan maka tubuh akan dapat menetralisir karbamat. ${ }^{9}$

Berdasarkan hasil uji statistik dengan chisquare didapatkan $\mathrm{p}=0.395$, berarti tidak terdapat hubungan yang bermakna antara lama penggunaan obat anti nyamuk bakar dengan penurunan kadar kolinesterase darah pada masyarakat Kelurahan Jati Rumah Gadang Padang. Hasil ini sama dengan penelitian sebelumnya yang dilakukan oleh Runia di Kabupaten Magelang pada tahun 2008 bahwa tidak terdapat hubungan yang bermakna antara lama paparan organofosfat dan karbamat terhadap 
penurunan kadar kolinesterase. ${ }^{9}$

Penurunan kadar kolinesterase adalah penanda klinis berbagai kondisi, termasuk gejala keracunan organofosfat dan karbamat. Keracunan organofosfat dan karbamat tidak hanya ditentukan berdasarkan lama penggunaan, namun juga dipengaruhi oleh dosis, lama paparan dan toksisitas dari organofosfat dan karbamat. ${ }^{2,10}$

Perbedaan hasil penelitian dengan literatur yang ada mungkin disebabkan berbagai keterbatasan yang terjadi selama penelitian. Pada penelitian ini tidak semua responden dapat diikutsertakan karena termasuk dalam kriteria eksklusi. Penelitian ini tidak memperhitungkan faktor-faktor lain yang mempengaruhi penurunan kadar kolinesterase. Kadar kolinesterase yang rendah juga berhubungan dengan status gizi, gangguan kesehatan (hepatitis, miestenia gravis, dII), umur, dosis, dan tingkat pendidikan.

Keterbatasan ini menyebabkan hasil yang diperoleh belum bisa menggambarkan keadaan yang sebenarnya, namun diharapkan tetap dapat memberi manfaat dalam upaya pencegahan terhadap penurunan kadar kolinesterase darah.

\section{KESIMPULAN}

Masyarakat Kelurahan Jati Rumah Gadang Padang yang menjadi 23 responden pada penelitian ini, 18 responden diantaranya menggunakan obat anti nyamuk bakar lebih dari 5 tahun.

Kadar kolinesterase masyarakat Kelurahan Jati Rumah Gadang yang menjadi responden pada penelitian ini terdapat sembilan responden mengalami penurunan dibawah normal, namun tidak dikategorikan keracunan. Terdapat 12 responden yang mengalami penurunan kadar kolinesterase dan dikategorikan keracunan karena memiliki kadar kolinesterase $<2751 \mathrm{U} / \mathrm{L}$.

Lama penggunaan obat anti nyamuk bakar tidak berhubungan dengan penurunan kadar kolinesterase darah.

Gangguan kesehatan yang banyak dialami responden adalah kejang otot lengan, sakit kepala, peningkatan sekresi air mata, batuk berdahak dan otot wajah kaku.

\section{DAFTAR PUSTAKA}

1. Afriyanto. Kajian keracunan pestisida pada petani penyemprot cabe di Desa Candi Kecamatan Bendungan kabupaten Semarang (tesis). Semarang: Program Pasca Sarjana Universitas Diponegoro; 2008.

2. Gallo MA, Lawryk NJ. Organic phosphorus pesticides. Dalam: Handbook of Pesticide Toxicology.1991.

3. Purba IG. Analisis faktor-faktor yang berhubungan dengan kadar kolinesterase pada perempuan usia subur di daerah pertanian (tesis). Semarang: Program Pasca Sarjana Universitas Diponegoro; 2009.

4. Ganong WF. Buku ajar fisiologi kedokteran. Jakarta: EGC; 2003.

5. Gita $P$. Bahaya obat anti nyamuk bakar. (serial online) 2011 (diunduh 9 desember 2012). Tersedia dari: URL: HYPERLINK http://www.gitapertiwi.org/ media-publikasi/artikel/168-bahaya-obat-anti-nya muk-dan-cara-penanggulangannya.html

6. Guyton AC, Hall J. Buku ajar fisiologi kedokteran. Jakarta: EGC; 2007.

7. Holzheim. Diagnostic reagen for quantitative in vitro determination of cholinesterase (ChE) in serum or plasma on photometric systems. 2008.

8. World Health Organization (WHO). Pestisida. (serial online) 2012 (diunduh 9 Desember 2012). Tersedia dari: URL: HYPERLINK http://www.who. int/bulletin/volumes/86/3/07-041814/en/

9. Runia YA. Faktor-faktor yang berhubungan dengan keracunan pestisida organofosfat, karbamat dan kejadian anemia pada petani hortikultura di Desa Tejosari Kecamatan Ngeblak Kabupaten Magelang (tesis). Semarang: Program Pasca Sarjana Universitas Diponegoro; 2008.

10. Joyce LK, Evelyn RH. Pharmacology a nurcing process approach. Jakarta: EGC; 1996. 